\title{
SINGA DALAM KESENIAN HINDU \\ DI JAWA TENGAH
}

\section{Oleh: Timbul Haryono}

\section{I}

Di Jawa Tengah banyak peninggalan-peninggalan arkeologi baik yang berupa bangunan, arca maupun artefak yang lain. Artefak-artefak tersebut dibuat oleh masyarakat pendukungnya untuk memenuhi kebutuhan hidupnya berupa kebutuhan rokhani atau kebutuhan jasmani.

Artefak sebagai alat untuk pemenuhan kebutuhan rokhani tentu saja dalam hal pembuatannya baik yang menyangkut penentuan bentuk maupun pemilihan dekorasinya akan terikat oleh adanya aturanaturan tertentu yang berhubungan dengan masalah keagamaan. 1. Meskipun demikian suatu kebebasan dalam diri si seniman masih ada sampai pada batas-batas tertentu.

Mengingat adanya hubungan yang erat antara hasil kesenian dengan keagamaan, maka pengamatan terhadap ragam hias yang terlukis pada benda-benda yang mempunyai nilai keagamaan, sedapat mungkin diusahakan untuk mencari makna yang tersembunyi di balik ragam hias tersebut. Nenek moyang kita lebih cenderung menyampaikan pesanpesan yang berhubungan dengan masalah falsafah hidup melalui simbol-simbol.

Ragam hias yang terdapat di dalam kesenian Jawa Hịdu secara umum dapat digolongkan atas gambar-gambar anthropomorf, gambargambar binatang, tumbuh-tumbuhan dan pola-pola geometris (van der Hoop, 1949).

Salah satu contoh yang akan dibicarakan dalam tulisan ini adalah gambar-binatang singa.

Sebenarnya penelitian terhadap fauna yang terdapat pada relief candi-candi di Jawa sudah pernah dilakukan oleh para ahli. Dapat dikemukakan di sini antara lain oleh van Erp yang meneliti kehadiran singa di candi Borobudur (van Erp, 1923: 39 - 54), kemudian oleh Steinmann yang mengadakan identifikasi fauna pada relief candi-candi di Jawa. Penelitian yang terakhir dilakukan oleh S. Kadarsan (S. Kadarsan et al., 1977: 3-11).

Menurut penelitian para ahli tersebut, binatang singa (Phantera leo) adalah binatang asing yang tidak terdapat di pulau Jawa. Oleh 
karena itu hadirnya binatang asing pada relief candi di pulau Jawa, memberikan petunjuk bahwa para pemahat banyak dipengaruhi oleh faktor-faktor dari luar. Faktor-faktor tersebut mungkin berupa: (1) tenaga-tenaga asing (orang Hindu) yang diperbantukan kepada para pemahat; (2) ada contoh-contoh gambar, model atau uraian tertulis; (3) para pemahat telah pernah melihat binatang-binatang tersebut di luar lingkungannya. Kalau singa dikatakan sebagai binatang asing, hal ini dapat dilihat dari hasil pahatan bahwa binatang yang jarang dijumpai atau tidak ada di pulau Jawa seperti singa, hasilnya banyak yang tidak wajar (S. Kadarsan et al., 1977:7).

Jika dalam karangan ini dibicarakan masalah binatang singa dalam kesenian Jawa Hindu, bukanlah ditujukan untuk mengkaji kembali penelitian yang pernah dilakukan oleh para ahli terdahulu. Seperti telah kita ketahui bahwa dapat dilihat adanya pahatan singa pada candicandi bersifat budha seperti candi Borobudur, candi Ngawen (Timbul Haryono, 1980).

Demikian pula pada candi yang bersifat saiwa ditemukan pula patung singa yaitu di candi apit kompleks percandian Lara Jonggrang (Prambanan). Suatu contoh yang menarik ialah pahatan singa pada sebuah yoni.

Masalahnya ialah apakah patung atau relief singa tersebut semata-mata hanya bersifat dekoratif saja? Tidakkah ada makna yang tersembunyi terhadap pemilihan hiasan tersebut? Pertanyaan tersebut tidak dapat dijawab dengan begitu mudah, karena yang kita hadapi adalah benda-benda hasil kegiatan nenek moyang yang telah punah.

Demikianlah sukarnya maka Th. van der Hoop mengatakan bahwa:

De betekenis van een siermotif is niet makkleijk in een enkel woord weer te geven - dikwijls is die betekenis zelf in het geheel niet zeker. De kunstenaar, die een bepaald motief gebruikt doet dit soms zonder de betekenis te kennen, alleen omdat hij het zo van zijn meester geleerd heeft. Wil men die betekenis onderzoeken, dàn zal men dikwijls diep in de geschiedenis en zelf in de praehistorie moeten teruggrijpen (Th. van der Hoop, 1949: 7).

Akan tetapi kalau diingat bahwa binatang singa adalah binatang asing yang hidupnya pada zaman dahulu ada di India, maka singa sebagai lambang dan sebagai gambar hias, datang di Indonesia bersama dengan kebudayaan Hindu (Th. van der Hoop, 1949:150). Oleh karena itu untuk menerka makna simbolis pahatan singa, seharusnyalah kembali kepada sumbernya yaitu di India. Tentang arti singa sebagai perlambang memang belum banyak yang diselidiki (Bosch, 1948:151). 
Dalam kesenian kuna di Iran, Mesopotamia dan Mesir, relief singa dianggap sebagai simbol matahari (Benjamin Rowland, 1959:40). Unsur kesenian ini kemudian mempengaruhi kebudayaan di India, seperti terlihat pada stambha-stambha yang puncaknya dihias dengan pahatan arca binatang antara lain singa. ${ }^{2}$.

\section{II}

Pokok permasalahan dalam tulisan ini adalah pahatan singa yang terdapat pada sebuah bangunan candi dan sebuah contoh lagi ialah pada sebuah yoni. Tidak semua pahatan singa akan dibahas - pun pula tidak mungkin - dalam karangan yang singkat ini.

\section{Arca singa di candi apit (Lara Jonggrang).}

Di kompleks percandian Lara Jonggrang ada dua buah bangunan yang disebut candi apit yaitu candi apit selatan yang menghadap ke utara dan candi apit utara menghadap ke selatan. Kedua bangunan ini memiliki denah, ukuran serta bentuk arsitektur yang sama. Peletakan kedua bangunan ini sedemikian rupa sehingga seolah-olah mengapit dan menjaga bangunan utama yaitu candi Siwa, candi Wisnu dan candi Brahma. ${ }^{3}$.

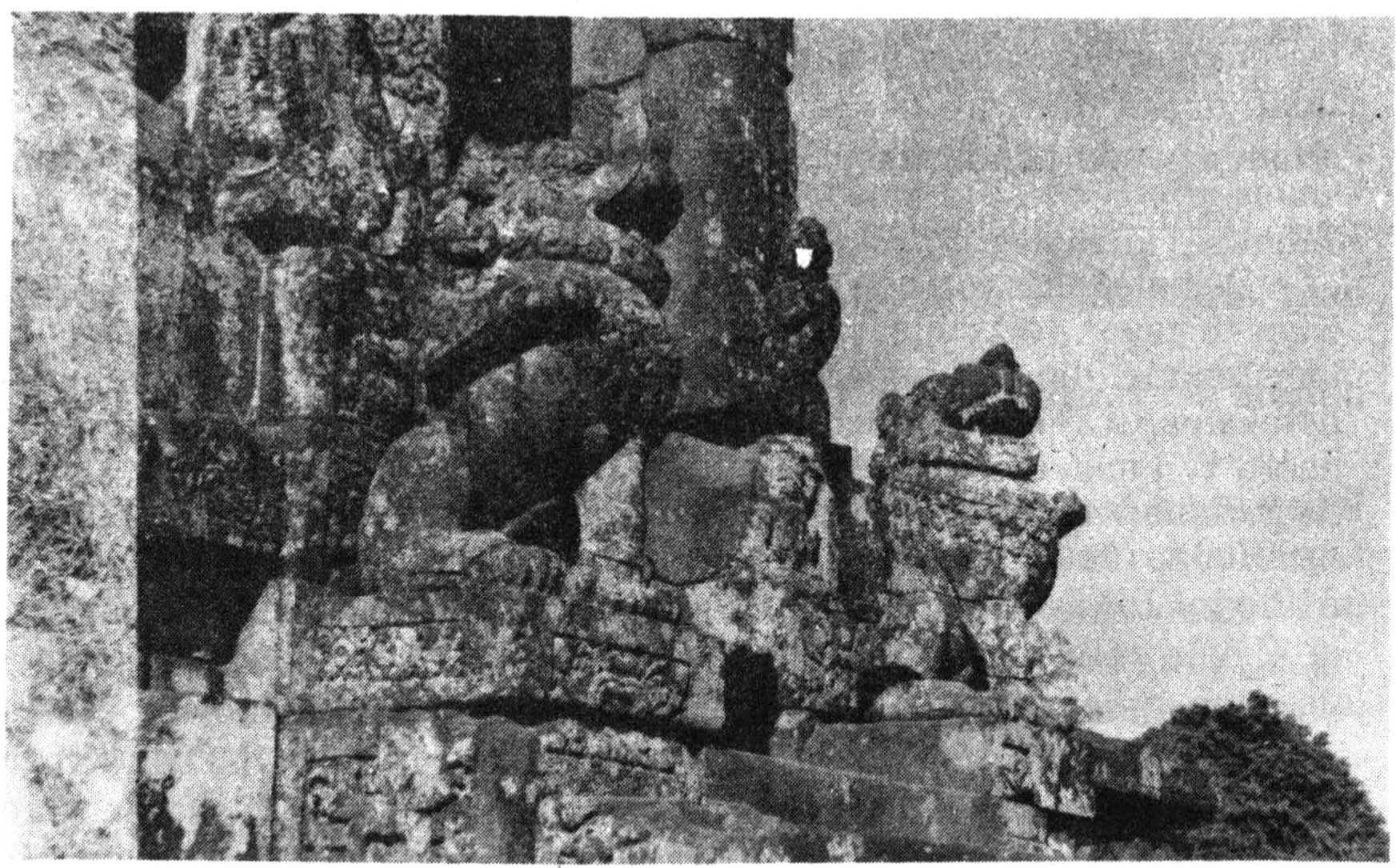

Patung Singa di Candi Apit (Lara Jonggrang) 
Di depan candi apit selatan diletakkan dua buah patung singa masing-masing di kanan-kiri pintu masuk ${ }^{4}$. Patung singa tersebut digambarkan dalam sikap duduk pada kedua kaki belakang. Sedangkan kaki depan satu lurus ke bawah, kaki yang lain diangkat ke atas. Penggarapan kedua patung ini sangat simetris. Patung singa yang ada di sebelah kanan pintu masuk kepalanya digambarkan sedikit miring ke kanan, dan kaki depan sebelah kanan di angkat ke atas. Sebaliknya patung singa di sebelah kiri pintu masuk kepalanya agak miring ke kiri dan kakidepan sebelah kiri diangkat ke atas.

Penempatan patung singa di depan pintu dapat dilihat juga di candi Borobudur. Menurut van Erp penempatan patung singa di kanan kiri pintu masuk bangunan suci merupakan tradisi dari India. Binatang singa ini di India dianggap sebagai tokoh penjaga pintu bangunan stupa (van Erp, 1924:39).

Penempatan patung singa di candi Ngawen lain lagi. Di sini patung singa ditempatkan pada ke empat sudut kaki candi, dengan sikap berdiri di atas kedua kaki belakang. Kedua kaki depan diangkat ke atas seolah-olah menggambarkan sikap siap menerkam.

Berkenaan dengan arti simbolis pahatan singa pada bangunan candi áda beberapa sumber yang dapat dipakai untuk menjelaskannya. Di dalam Silpa Prakasa di jelaskan bahwa ragam hias singa dengan ekspresi wajah yang buas merupakan hiasan yang terpilih untuk suatu bangunan candi. Bahkan dinyatakan bahwa tanpa patung singa maka suatu bangunan suci termasuk bangunan dari tipe yang paling rendah dan tidak baik (niriha) (Alice Boner, 1966:116-118).

Untuk menggambarkan sikap, kejantanan atau kepahlawanan serta kebuasannya, maka berbagai tipe singa akan ditonjolkan. Tipe-tipe singa yang dianggap baik adalah:

1. Viraja

2. Jagrata

3. Udyata
: Tipe singa demikian ini digambarkan badannya membalik dan melihat ke belakang. Ia selalu berdiri di atas kedua kaki belakang. Sikap demikian ini disebut simhavalokana.

: Singa tipe demikian ini digambarkan dengan wajah yang sangat angkuh buas (mattarupina). Ia bersikap duduk dengan cakar di angkat ke atas dan disebut khummana simha.

: Singa tipe demikian ini digambarkan duduk dengan kedua kaki belakang dan biasanya ditempatkan di atas suatu tempat yang tinggi. Penggambaran demi- 
kian ini seolah-olah ia siap untuk meloncat menerkam siapapun yang beniat jahat. Ia terkenal dengan sebutan jhampa-simha.

4. Gajakranta : Singa tipe ini digambarkan duduk dengan ketiga kakinya di atas raja gajah. Sedang salah satu kaki depan diangkat di depan dadanya, seolah-olah siap untuk mencekamnya (trasita). Singa demikian ini lebih dikenal dengan sebutan simha kunjara.

Berdasarkan atas uraian-uraian yang bersumber pada Silpa Prakasa tersebut dan kemudian diperbandingkan dengan patung singa candi apit, maka dapat disimpulkan bahwa penempatan patung singa tersebut jelas bersumber dari kebiasaan di India. Arti simbolis patung tersebut adalah sebagai penjaga dari pengaruh-pengaruh jahat. Selain itu juga untuk mendapatkan sifat keagungan terhadap bangunan candi utama. Pemilihan terhadap candi apit untuk penempatan patung singa rupa-rupanya tidak tanpa alasan, karena candi apit sendiri seolah-olah sebagai penjaga atau pengawal candi-candi utama.

Bahkan bukan hanya singa dalam bentuk patung saja yang menghiasi candi apit, akan tetapi juga singa dalam bentuk relief. Relief singa ini dipahatkan di pipi tangga naik candi apit. Singa digambarkan dalam sikap duduk dengan kedua kaki belakang. Kaki depan diangkat ke atas. Dari badannya dipahatkan pola hiasan tumbuh-tumbuhan berbentuk sulur-sulur.

Untuk mendapatkan rasa agung terhadap kompleks percandian Lara Jonggrang sebagai candi kerajaan, maka pada kaki candi dibuatkan relung-relung untuk menempatkan patung singa yang di apit oleh pohon kalpataru. Motif hiasan demikian ini - karena satu-satunya didapatkan di Prambanan - kemudian terkenal dengan sebutan 'motif 'Prambanan' (Bernet Kempers, 1959: 62)

\section{Relief singa-gajah pada sebuah yoni.}

Di Kantor Suaka Peninggalan Sejarah dan Purbakala (wilayah DIY) disimpan sebuah yoni yang sangat menarik yaitu hiasan di bawah cerat 5 . Yoni tersebut berukuran: tinggi $95 \mathrm{~cm}$; sisi bagian bawah $134,5 \times 134,5 \mathrm{~cm}$, sedangkan sisi bagian atas $102 \times 101 \mathrm{~cm}$. Lubaing yoni berukuran $32,5 \times 32,5 \mathrm{~cm}$. Baik bingkai bawah maupun bingkai atas terdiri atas kombinasi bingkai persegi dan bingkai sisi genta.

Pada umumnya relief yang dipahatkan pada yoni berupa binatang naga, kura-kura atau garuda secara terpisah atau berkombinasi (Soejatmi Satari, 1978). Agar jelasnya dapat dilihat dalam daftar berikut: 
No. Lokasi atau tempat sekarang H i a s a n

$\begin{array}{rll}1 & \text { Candi Siwa (Prambanan) } & \text { Naga } \\ 2 & \text { Candi Bråhma (Prambanan) } & \text { Naga } \\ 3 & \text { Candi Wisnu (Prambanan) } & \text { Naga } \\ 4 & \text { Tanjung (Kalasan) } & \text { Naga } \\ 5 & \text { Tanjungtirto (Kalasan) } & \text { Naga } \\ 6 & \text { Museum Pusat (no 366). } & \text { Naga } \\ 7 & \text { Petungkriyono (Pekalongan) } & \text { Naga } \\ 8 & \text { Candi Ijo } & \text { Naga; Kura-kura } \\ 9 & \text { Candi Canggal } & \text { Naga; Kura-kura } \\ 10 & \text { Candi Sambisari } & \text { Naga; Kura-kura } \\ 11 & \text { Dk. Buluskulon (Bantul) } & \text { Naga; Kura-kura } \\ 12 & \text { R.S. Pugeran (Yogyakarta) } & \text { Naga; Kura-kura; Garuda } \\ 13 & \text { Museum Pusat (no 359) } & \text { Naga, Kura-kura, Garuda } \\ 14 & \text { Museum Pusat (no 360) } & \text { Naga, Kura-kura, Garuda } \\ 15 & \text { Museum Sumenep (Madura) } & \text { Naga, Garuda } \\ 16 & \text { Candi Bowongan } & \text { Kura-kura, Garuda } \\ 17 & \text { Museum Sanabudaya } & \text { Kura-kura, Garuda } \\ 18 & \text { Candi Merak } & \text { Naga, Kura-kura, Lembu }\end{array}$

Dari beberapa contoh hiasan seperti terlihat pada daftar di atas dapatlah dikatakan bahwa secara umum unsur-unsur hiasan pada yoni sama yaitu terdiri atas: naga, kura-kura, garuda. Variasi penempatannya bermacam-macm ada yang dilukiskan di bawah cerat, dan ada pula yang dilukiskan di tubuh yoni. Kita melihat bahwa seakan-akan ada suatu aturan yang harus diikuti oleh para pemahat dalam menentukan pilihan hiasannya. Adanya pola hiasan yang teratur tersebut ditentukan oleh makna simbolis yang terkandung pada unsur hiasannya.

Ketiga jenis binatang yang menjadi pola hiasan pada yoni itu terdapat dalam cerita Amrtamanthana dan Garudeya. Cerita ini intinya adalah sekitar pencarian air amrta (Juinboll, 1906; Soekmono, 1952: 35-39). Air merupakan unsur yang esensiil dalam hubungannya dengan yoni yang sekaligus sebagai penampung air suci.

Oleh karena itu kalau ditemukan yoni yang berhiaskan singa-gajah memang menarik untuk diperhatikan. Relief ini digambarkan di bawah cerat. Singa digambarkan duduk dengan kedua kaki belakang di atas punggung seekor gajah. Kedua kaki depannya - meskipun sudah patah sangat boleh jadi ditekuk ke atas di depan badannya. Ekspresi wajah- 
nya dilukiskan tampak buas, dengan gigi-gigi yang tajam. Lidahnya menjulur ke luar.

Adapun si gadjah dilukiskan mendekam di atas sebuah lapik yang berhiaskan bunga-bunga. Kedua kaki depan ditekuk. Belalai melingkar di antara kedua kakinya. Berbeda dengan wajah singa, maka ekspresi wajahnya tampak kasihan sekali seolah-olah tunduk takluk di bawah singa 6 .

Pertanyaannya sekarang ialah apa makna simbolis relief tersebut? Menurut sumber (Silpa Prakasa) singa merupakan 'figure of symbolic animals' yang sangat terkenal di India. Disebutkan bahwa ia telah berhasil menaklukkan gajah simbol kejahatan, sehingga singa ini disebut dengan Gajaraja. Singa adalah musuh 'bebuyutan' gajah. Perkelahian antara keduanya melambangkan peperangan antara yang baik melawan yang buruk. Kedua sifat ini (sifat baik - buruk, terang - gelap) selalu terdapat di dunia dan did alam diri manusia.

Menurut sumber yang lain ialah Kurma Purana diuraikan bagaimana dewa Siwa memakai pakaian dari kulit gajah. Diceritakan bahwa pada suatu ketika para brahmana sedang mengadakan persembahan terhadap lingga. Tiba-tiga muncul seorang raksasa (asura) yang menjelma seekor gajah. Gajah penjelmaan tersebut menyerang para brahmana. Kemudian dewa Siwa muncul dan membunuh gajah tersebut yang kemudian memakai kulit gadjah sebagai pakaiannya (Gupta, 1972: 41).

Di dalam naskah Suprabhedagama dijumpai keterangan yang lain lagi. Seorang raja asura yang bernama Andhaka berniat untuk melarikan dewi Parwati isteri Siwa. Untuk melaksanakan niat jahatnya tersebut ia dibantu seorang raksasa bernama Nila yang menjelma menjadi seekor gajah akan membunuh Siwa. Mengetahui rencana ini maka Virabhadra menjelma sebagai seekor singa. Akhirnya alam peperangan tersebut Virabhadra dapat membunuh Nila.

Dari keterangan yang dicukil di atas dapat diketahui bahwa singa adalah identik dengan aspek desțuktif dewa Siwa untuk menaklukkan asura. Dalam hal demikian ini dewa Siwa disebut sebagai Gajasurasamharamurti.

\section{III}

Demikianlah gambaran tentang singa dalam kesenian Hindu yang terlukis pada bangunan suci atau benda-benda suci yang lain. Daŕi uraian dimuka terlihat bahwa pahatan dalam kesenian Hindu tidak 
semata-mata merupakan unsur dekoratif saja, akan tetapi - dan lebihlebih lagi - mengandung makna simbolis dalam falsafah hidup manusia.

Singa merupakan simbol dari aspek baik sedangkan gajah sebagai simbol aspek jahat. Keduanya merupakan pasangan yang selalu bertentangan dan selalu ada dalam sifat-sifat manusia. Kejahatan akan hancur oleh kejujuran dan kesucian.

Yogyakarta, 25 Maret 1980

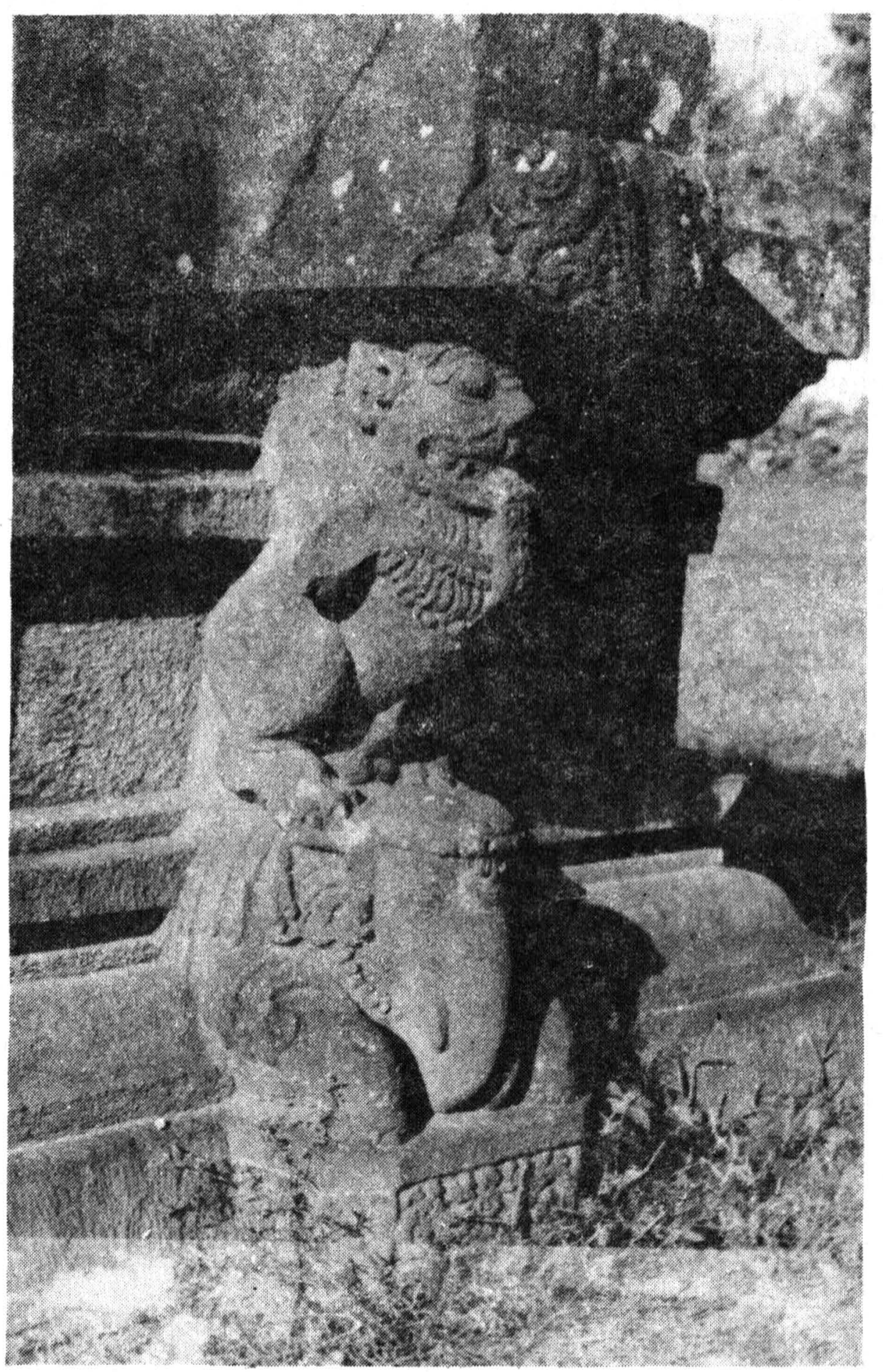

.Hiasan Singa - Gajah di bawah cerat Yoni. 


\section{Catatan:}

1. Pada jaman klasik hasil-hasil kesenian mempunyai hubungan erat dengan keagamaan.

2. Puncak stambha Asoka di Sarnath dihias dengan pahatan singa berjumlah empat. Kesemuanya bersikap duduk saling membelakangi.

3. Karena peletakan yang demikian ini maka candi tersebut mendapat nama 'candi apit'.

4. Di candi apit utara tidak didapatkan patung singa. Ini tidak berarti bahwa di candi apit utara tidak ditempatkan arca singa. Mengingat pola keletakannya yang simetris dan juga kesamaan segi arsitekturnya, sangat boleh jadi di depan candi apit utara pada mulanya juga ada patung singa.

5. Yoni ini aslinya ditemukan di tengah sawah di sebelah barat desa Bogem (Kalasan). Tanah di sekeliling yoni pernah digali (ekskavasi percobaan) oleh Kantor Suaka Sejarah \& Purbakala Prambanan, namun hasilnya kurang memuaskan.

6. Pada lokasi temuan-temuan arca di halaman kantor Suaka (Prambanan) salah satu diantaranya adalah patung singa naik gajah yang mungkin sekali aslinya ditempatkan di dalam relung. Akan tetapi belum jelas lokasi aslinya. 


\section{DAFTAR PUSTAKA:}

Bernet Kempers, A.J.,

1959 Ancient Indonesian Art. Amsterdam, C.P.J. van der Peet.

Bosch, F.D.K.

1948 De Gouden Kiem. Inleiding in de Indische symboliek. Amsterdam.

Erp, Th. Van

1923 'De Leeuwen van den Borobudur', O.V. 's.Hage,' M. Nijheff, halm. 39-54.

Gopinatha Rao, T.A.

1914 Elements of Hindu Iconography. Vol. I

1916 Elements of Hindu Iconography Vol. II

Madras, The Law Printing House, Mount Road

Gupte, R.S

1972 Iconography of the Hindus Buddhists and Jains.

Bombai, D.B. Taraporevala Sons \& Co Private Ltd.

Haryono, Timbul

1980 Kompleks Candi Ngawen. Paper untuk kuliah kerja . Jurusan Arkeologi (Tidak diterbitkan)

Hoop, A.N.J. Th. a Th. van der

1949 Indonesische Siermotieven. K.B.G.

Juinboll, H.H.

1906 Adiparwa. Oudjavaansch proza geschrift, 's-Gravenhage, Martinus Nijhoff.

Kadarsan, S.; S. Somadikarta dan M. Djajasamita,

1977 "Fauna asing pada relief candi-candi di pulau Jawa" MISI VII, No 2 halm 1-11

Rowland, Benyamin.

1959 The art and architecture. of India. Harmondworth Penguin Book Ltd.

Soejatmi Satari,

1978 New finds in Northen Central Java. Bulletin of the Research Centre of Archeology, No. 13 Jakarta.

Soekmono

1952 "Amertamanthana", Amerta 1 Dinas Purbakala Republik Indonesia.

Steinmann,

1934 "Den dieren op de bas-reliefs van Borobudur" TBG 74, halm. 101-122. 